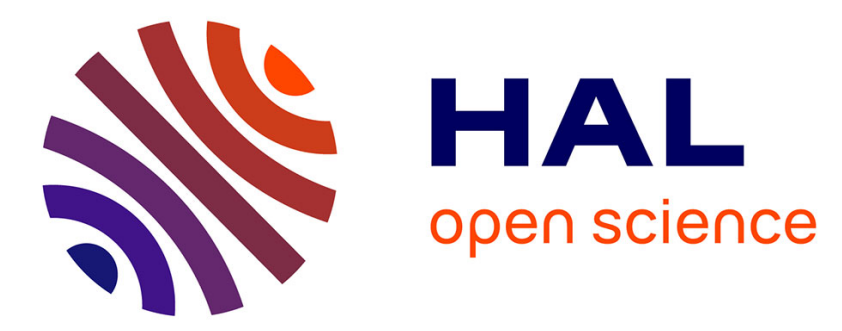

\title{
Cyclopentadienylniobium(V) Phosphine Chemistry: Adduct Formation vs Reduction. X-ray Structure of $\mathrm{CpNbCl4}(\mathrm{PMePh} 2)$
}

\author{
James Fettinger, D. Webster Keogh, Rinaldo Poli
}

\section{- To cite this version:}

James Fettinger, D. Webster Keogh, Rinaldo Poli. Cyclopentadienylniobium(V) Phosphine Chemistry: Adduct Formation vs Reduction. X-ray Structure of CpNbCl4(PMePh2). Inorganic Chemistry, 1995, 34 (9), pp.2343-2347. 10.1021/ic00113a014 . hal-03531736

\author{
HAL Id: hal-03531736 \\ https://hal.science/hal-03531736
}

Submitted on 18 Jan 2022

HAL is a multi-disciplinary open access archive for the deposit and dissemination of scientific research documents, whether they are published or not. The documents may come from teaching and research institutions in France or abroad, or from public or private research centers.
L'archive ouverte pluridisciplinaire HAL, est destinée au dépôt et à la diffusion de documents scientifiques de niveau recherche, publiés ou non, émanant des établissements d'enseignement et de recherche français ou étrangers, des laboratoires publics ou privés. 


\title{
Cyclopentadienylniobium(V) Phosphine Chemistry: Adduct Formation vs Reduction. $\mathrm{X}$-ray Structure of $\mathrm{CpNbCl}_{4}\left(\mathrm{PMePh}_{2}\right)$
}

\author{
James C. Fettinger, D. Webster Keogh, and Rinaldo Poli*,† \\ Department of Chemistry and Biochemistry, University of Maryland, College Park, Maryland 20742
}

Received November 2, $1994^{\circledR}$

\begin{abstract}
The reaction between $\mathrm{CpNbCl}_{4}$ and the phosphine ligands $\mathrm{PMe}_{x} \mathrm{Ph}_{3-x}(x=0,1,2,3)$ has been investigated. While no reaction occurs with $\mathrm{PPh}_{3}$, stable adducts are formed with all the other ligands in the above series. These have been isolated and characterized by elemental analysis, ${ }^{1} \mathrm{H}$ and ${ }^{31} \mathrm{P}-\mathrm{NMR}$ spectroscopy, and an X-ray structural determination for the $\mathrm{PMePh}_{2}$ adduct. The three phosphines $\mathrm{PMe}_{3}, \mathrm{PMe}_{2} \mathrm{Ph}$, and $\mathrm{PMePh}_{2}$, however, also engage in a subsequent reduction process with formation of $\mathrm{Cl}$ radicals and $\mathrm{Nb}(\mathrm{IV})$ complexes. $\mathrm{CpNbCl}_{3}-$ $\left(\mathrm{PMe}_{3}\right)_{2}$ has been independently synthesized from $\mathrm{CpNbCl}_{4}, \mathrm{Na}$, and $\mathrm{PMe}_{3}$ in a 1:1:2 ratio and fully characterized. The relative rate of reduction depends on the nature of the phosphine, increasing in the order $\mathrm{PMePh}_{2}<\mathrm{PMe}_{2} \mathrm{Ph}$ $<\mathrm{PMe}_{3}$. X-ray data for $\mathrm{CpNbCl}_{4}\left(\mathrm{PMePh}_{2}\right)$ : monoclinic, $C 2 / c, a=23.818(2) \AA, b=12.4719(10) \AA, c=15.8137$ (12) $\AA, \beta=106.365(7)^{\circ}, V=4507.2(6) \AA^{3}, Z=8, D_{\mathrm{x}}=1.609 \mathrm{~g}^{\circ} \mathrm{cm}^{-3}, \mu(\mathrm{Mo} \mathrm{K \alpha})=0.603 \mathrm{~mm}^{-1}, R=0.0349$ for 329 parameters and 3989 data with $I>2 \sigma(I)$. The structure shows a distorted pseudooctahedral geometry with the $\mathrm{Cp}$ and $\mathrm{PMePh}$ ligands occupying two axial coordination sites and the four equatorial $\mathrm{Nb}-\mathrm{Cl}$ bonds being bent away from the $\mathrm{Cp}$ ring.
\end{abstract}

\section{Introduction}

We have recently explored the chemistry of intermediate oxidation state cyclopentadienylmolybdenum complexes, with a particular interest in how the adoption of an electronic configuration with more than one unpaired electron contributes to the energetic stabilization of electronically unsaturated configurations. ${ }^{1}$ A delicate balance between spin triplet 16electron complexes and their diamagnetic saturated adducts with 2-electron donors has been observed for both Mo(IV) systems, e.g. $\mathrm{CpMoCl}_{3}\left(\mathrm{PMe}_{2} \mathrm{Ph}\right)_{n}\left(n=1,2 ; \mathrm{Cp}=\mathrm{C}_{5} \mathrm{H}_{5}\right),{ }^{2}$ and $\mathrm{Mo}(\mathrm{II})$ systems, e.g. $\mathrm{Cp} * \mathrm{MoCl}\left(\mathrm{PMe}_{3}\right)_{n}\left(n=2,3 ; \mathrm{Cp}^{*}=\mathrm{C}_{5} \mathrm{Me}_{5}\right)^{3}$

In an effort to expand these studies to analogous systems of niobium, we set out to synthesize a number of phosphine adducts of cyclopentadienylniobium chloride systems in a variety of oxidation states. These systems are conveniently accessed from $\mathrm{CpNbCl}_{4}$ and the ligand of interest under reducing conditions, as has been extensively exploited by others before, for instance for the preparation of $\mathrm{CpNbCl}_{2}\left(\mathrm{PMe}_{3}\right)_{3},{ }^{4} \mathrm{Cp}^{*} \mathrm{NbCl}_{2}\left(\mathrm{PR}_{3}\right)_{2}$ $\left[\left(\mathrm{PR}_{3}\right)_{2}=\left(\mathrm{PMe}_{3}\right)_{2},\left(\mathrm{PMe}_{2} \mathrm{Ph}\right)_{2}, \mathrm{dmpe}\right]^{5.6}$ and $\mathrm{CpNbCl}_{3}(\mathrm{~L}-\mathrm{L})(\mathrm{L}-\mathrm{L}$ $=$ dmpe $^{7}$ dppe $^{8}$ ).

When the ligand is added to $\mathrm{CpNbCl}_{4}$ before the addition of the reducing agent, simple adducts of type $\mathrm{CpNbCl}_{4}(\mathrm{~L})$ are presumed to form. The situation concerning the formation of these adducts is, however, not completely clear. Leigh $e$ t al. first reported in 1978 that the reaction between $\mathrm{CpNbCl}_{4}$ and

${ }^{\dagger}$ Alfred P. Sloan Research Fellow, 1992-1994; Presidential Young Investigator, 1990-1995.

\& Abstract published in Advance ACS Abstracts, April 15, 1995.

(1) Poli, R. Comments Inorg. Chem. 1992, 12, 285.

(2) Abugideiri, F.; Gordon, J. C.; Poli, R.; Owens-Waltermire, B. E.; Rheingold, A. L. Organometallics 1993, 12, 1575.

(3) Abugideiri, F.; Keogh, D. W.; Poli, R. J. Chem. Soc., Chem. Commun. 1994, 2317.

(4) Alt, H. G.; Engelhardt, H. E. Z. Naturforsch. 1989, 44B, 367.

(5) Siemeling, U.; Gibson, V. C. J. Organomet. Chem. 1992, 424, 159.

(6) de la Mata, J.; Galakhov, M. V.; Gómez, M.; Royo, P. Organometallics $1993,12,1189$.

(7) Bunker, M. J.; Green, M. L. H. J. Chem. Soc., Dalton Trans. 1981, 85 .

(8) Daran, J.-D.; Prout, K.; DeCian, A.; Green, M. L. H.; Siganporia, N. J. Organomet. Chem. 1977, 136, C4.
$\mathrm{PMe}_{3}$ or $\mathrm{PEt}_{3}$ leads to labile adducts but pure products could not be isolated. ${ }^{9}$ It was also shown in these studies ${ }^{9 \mathrm{~b}}$ that the corresponding tantalum system, $\mathrm{CpTaCl}_{4}$, forms stable adducts with bipy, $\mathrm{MeOCH}_{2} \mathrm{CH}_{2} \mathrm{OMe}, \mathrm{PMe}_{3}$, and $\mathrm{PCy}_{3}$, but it is stated that the adducts with other (presumably less basic) phosphines are too labile to isolate. Labile adducts of formula $\mathrm{Cp}^{\prime} \mathrm{NbCl}_{4}(\mathrm{~L})$ $\left(\mathrm{Cp}^{\prime}=\mathrm{C}_{5} \mathrm{H}_{4} \mathrm{Me}\right)$ were also reported by Green et al. with $\mathrm{L}=$ $\mathrm{MeCN}, \mathrm{PhCN}, \mathrm{P}(\mathrm{OMe})_{3}$ and dppe; ${ }^{10}$ although these materials were isolated in an analytically pure form, they showed tendency for decomposition in solution. Subsequently, however, Yasuda et al. mentioned the isolation of stable $\mathrm{CpNbCl}_{4}(\mathrm{~L})\left(\mathrm{L}=\mathrm{PMe}_{3}\right.$, $\left.\mathrm{PEt}_{3}, \mathrm{P}(\mathrm{OMe})_{3}\right)$ derivatives, but report for them only color and melting point. ${ }^{11}$ The only stable and fully characterized ligand adduct of a cyclopentadienylniobium(V) system appears to be $\mathrm{Cp}^{*} \mathrm{NbCl}_{4}\left(\mathrm{CN}-2,6-\mathrm{Me}_{2} \mathrm{C}_{6} \mathrm{H}_{3}\right)$, recently reported by Royo et al. ${ }^{12}$

We report here our own studies of the reaction between $\mathrm{CpNbCl}_{4}$ and tertiary phosphine ligands, which shows formation of stable adducts so long as there is no excess phosphine present, while excess phosphine induces a subsequent reduction process. We also describe the X-ray structure of the adduct with $\mathrm{PMePh}_{2}$, the first phosphine adduct of cyclopentadienylniobium(V) to be crystallographically characterized. Further results in the reductive chemistry of these $\mathrm{Nb}(\mathrm{V})$ adducts will be described in subsequent publications.

\section{Experimental Section}

General Data. All operations were carried out under an atmosphere of dinitrogen or argon with standard Schlenk-line techniques. Solvents were purified by conventional methods and distilled under argon prior

(9) (a) Burt, R. J.; Leigh, G. J. J. Organomet. Chem. 1978, 148, C19. (b) Burt, R. J.; Leigh, G. J.; Hughes, D. L. J. Chem. Soc., Dalton Trans. 1981, 793.

(10) Bunker, M. J.; De Cian, A.; Green, M. L. H.; Moreau, J. J. E.; Siganporia, N. J. Chem. Soc., Dalton Trans.1980, 2155.

(11) Yasuda, H.; Okamoto, T.; Nakamura, A. Organometallic Syntheses; King, R. B., Eisch, J. J., Eds.; Elsevier: Amsterdam, 1988; Vol. 4; p 20.

(12) Alcalde, M. I.; de la Mata, J.; Gómez, M.; Royo, P.; Pellinghelli, M. A.: Tiripicchio. A. Organometallics 1994, 13, 462. 
Table 1. Analytical and spectroscopic data for $\mathrm{CpNbCl}_{4}(\mathrm{~L})\left(\mathrm{L}=\mathrm{PMe}_{3}, \mathrm{PMe}_{2} \mathrm{Ph}, \mathrm{PMePh}_{2}\right)$ and $\mathrm{CpNbCl}_{3}\left(\mathrm{PMe}_{3}\right)_{2}$

\begin{tabular}{|c|c|c|c|c|}
\hline \multirow[b]{2}{*}{ compd } & \multirow[b]{2}{*}{${ }^{\prime} \mathrm{H}-\mathrm{NMR}(\delta)^{a}$} & \multirow[b]{2}{*}{${ }^{31} \mathrm{P}-\mathrm{NMR}(\delta)^{a}$} & \multicolumn{2}{|c|}{ elemental anal. $(\%)^{b}$} \\
\hline & & & $\mathrm{C}$ & $\mathrm{H}$ \\
\hline $\mathrm{CpNbCl}_{4}\left(\mathrm{PMe}_{3}\right)$ & $\begin{array}{l}6.40(\mathrm{~s}, 5 \mathrm{H}, \mathrm{Cp}) \\
1.50\left(\mathrm{~d}, 9 \mathrm{H}, \mathrm{PMe}_{3}, J_{\mathrm{HP}}=11.5 \mathrm{~Hz}\right)\end{array}$ & $5(\mathrm{br})\left(\mathrm{w}_{1 / 2}=3456 \mathrm{~Hz}\right)$ & $25.84(25.56)$ & $3.53(3.76)$ \\
\hline $\mathrm{CpNbCl}_{4}\left(\mathrm{PMe}_{2} \mathrm{Ph}\right)$ & $\begin{array}{l}7.59\left(\mathrm{~m}, 2 \mathrm{H}, \mathrm{PMe}_{2} P h\right) \\
7.03\left(\mathrm{~m}, 3 \mathrm{H}, \mathrm{PMe}_{2} P h\right) \\
6.35(\mathrm{~s}, 5 \mathrm{H}, \mathrm{Cp}) \\
1.91\left(\mathrm{~d}, 6 \mathrm{H}, \mathrm{PMe}{ }_{2} \mathrm{Ph}, J_{\mathrm{HP}}=11.2 \mathrm{~Hz}\right)\end{array}$ & $12(\mathrm{br})\left(\mathrm{w}_{1 / 2}=3328 \mathrm{~Hz}\right)$ & $35.22(35.65)$ & $4.00(3.69)$ \\
\hline $\mathrm{CpNbCl}_{4}\left(\mathrm{PMePh}_{2}\right)$ & $\begin{array}{l}7.86\left(\mathrm{~m}, 4 \mathrm{H}, \mathrm{PMe} P h_{2}\right) \\
7.01\left(\mathrm{~m}, 6 \mathrm{H}, \mathrm{PMe} P h_{2}\right) \\
6.33(\mathrm{~s}, 5 \mathrm{H}, \mathrm{Cp}) \\
2.30\left(\mathrm{~d}, 3 \mathrm{H}, \mathrm{PMePh}_{2}, J_{\mathrm{HP}}=10.9 \mathrm{~Hz}\right)\end{array}$ & $17(\mathrm{br})\left(w_{1 / 2}=2126 \mathrm{~Hz}\right)$ & $43.0(43.2)$ & $3.97(3.63)$ \\
\hline $\mathrm{CpNbCl}_{3}\left(\mathrm{PMe}_{3}\right)_{2}$ & $\begin{array}{l}10\left(\mathrm{br}, w_{1 / 2}=6250 \mathrm{~Hz}\right) \\
-20\left(\mathrm{br}, w_{1 / 2}=7812 \mathrm{~Hz}\right)\end{array}$ & & $31.22(31.72)$ & $5.73(5.58)$ \\
\hline
\end{tabular}

to use. FT-IR spectra were recorded on a Perkin-Elmer 1800 spectrophotometer with $\mathrm{KBr}$ disks (Nujol mulls). NMR spectra were obtained with Bruker WP200 and AF200 spectrometers; the peak positions are reported downfield of TMS as calculated from the residual solvent peaks $\left({ }^{1} \mathrm{H}\right)$ or downfield of external $85 \% \mathrm{H}_{3} \mathrm{PO}_{4}\left({ }^{31} \mathrm{P}\right)$. For each ${ }^{3}$ P-NMR spectrum, a sealed capillary containing $\mathrm{H}_{3} \mathrm{PO}_{4}$ was immersed in the same NMR solvent used for the measurement and this was used as the reference. EPR spectra were recorded on a Bruker ER200 spectrometer equipped with an X-band microwave generator. Cyclic voltammograms were recorded with an EG\&G 362 potentiostat connected to a Macintosh computer through MacLab hardware/software; the electrochemical cell was a locally modified Schlenk tube with a $\mathrm{Pt}$ counterelectrode sealed through uranium glass/Pyrex glass seals. The cell was fitted with a $\mathrm{Ag} / \mathrm{AgCl}$ reference electrode and a $\mathrm{Pt}$ working electrode. All measurements were carried out in $\mathrm{CH}_{2} \mathrm{Cl}_{2}$ solution with $n-\mathrm{Bu}_{4} \mathrm{NPF}_{6}$ (ca. $0.1 \mathrm{M}$ ) as supporting electrolyte. Potentials are reported vs the $\mathrm{Cp}_{2} \mathrm{Fe} / \mathrm{Cp}_{2} \mathrm{Fe}^{+}$couple which was introduced into the cell at the end of each measurement. The elemental analyses were carried out by $\mathrm{M}-\mathrm{H}-\mathrm{W}$ Laboratories, Phoenix, $\mathrm{AZ}$. $\mathrm{CpNbCl}_{4}$ was prepared as previously described. ${ }^{11.13} \mathrm{PMe}_{3}, \mathrm{PPh}_{3}$ (Aldrich), $\mathrm{PMe}_{2} \mathrm{Ph}$, and $\mathrm{PMePh}_{2}$ (Strem) were used without further purification. Analytical and spectroscopic data for all new compounds are collected in Table 1.

Synthesis of $\mathbf{C p N b C l}_{4}\left(\mathbf{P M e}_{3}\right)$. To a toluene suspension $(10 \mathrm{~mL})$ of $\mathrm{CpNbCl}_{4}(0.449 \mathrm{~g}, 1.50 \mathrm{mmol})$ was added $\mathrm{PMe}_{3}(0.124 \mathrm{~mL}, 1.20$ $\mathrm{mmol}$ ), immediately producing a red-orange solution. After $5 \mathrm{~min}$ of stirring the solution was cannulated away from the unreacted starting material and into heptane $(35 \mathrm{~mL})$. A red-orange solid precipitated. The solid was filtered, washed with heptane $(3 \times 5 \mathrm{~mL})$, and dried under vacuum. Yield: $0.276 \mathrm{~g}, 62 \%$ based on $\mathrm{PMe}_{3}$. The compound can be recrystallized by diffusion of a heptane layer into a toluene solution.

Synthesis of $\mathrm{CpNbCl}_{4}\left(\mathrm{PMe}_{2} \mathrm{Ph}\right)$. This synthesis was carried out as described above for the $\mathrm{PMe}_{3}$ adduct. $\mathrm{CpNbCl}_{4}(0.344 \mathrm{~g}, 1.15 \mathrm{mmol})$ in toluene $(8 \mathrm{~mL})$ was treated with $\mathrm{PMe}_{2} \mathrm{Ph}(0.131 \mathrm{~mL}, 0.92 \mathrm{mmol})$. The solution was filtered into heptane $(25 \mathrm{~mL})$, precipitating a red solid. Yield: $0.308 \mathrm{~g}, 76 \%$ based on $\mathrm{PMe}_{2} \mathrm{Ph}$. The compound can be recrystallized by diffusion of a heptane layer into a toluene solution.

Synthesis of $\mathbf{C p N b C l}_{4}\left(\mathbf{P M e P h}_{2}\right)$. To a toluene suspension $(35 \mathrm{~mL})$ of $\mathrm{CpNbCl}_{4}(0.506 \mathrm{~g}, 1.69 \mathrm{mmol})$ was added $\mathrm{PMePh}_{2}(0.285 \mathrm{~mL}, 1.53$ $\mathrm{mmol}$ ), immediately producing a dark red-orange solution. After overnight stirring, the solution was concentrated to ca. half the original volume, and a red solid was precipitated by the addition of heptane $(20 \mathrm{~mL})$. Yield: $0.575 \mathrm{~g}, 75 \%$. The compound can be recrystallized by diffusion of a heptane layer into a toluene solution. A single crystal obtained by this method was used for the $\mathrm{X}$-ray analysis.

Synthesis of $\mathrm{CpNbCl}_{3}\left(\mathrm{PMe}_{3}\right)_{2}$. $\mathrm{CpNbCl}_{4}(0.564 \mathrm{~g}, 1.88 \mathrm{mmol})$ was added to a toluene solution $(40 \mathrm{~mL})$ of $\mathrm{PMe}_{3}(0.400 \mathrm{~mL}, 3.86 \mathrm{mmol})$ containing $\mathrm{Na} / \mathrm{Hg}(0.046 \mathrm{~g}, 2.00 \mathrm{mmol}$ in $6 \mathrm{~g}$ of $\mathrm{Hg})$ giving a redorange solution. After $30 \mathrm{~min}$ of stirring, the solution became green in color. After an additional $12 \mathrm{~h}$ of stirring at room temperature, the toluene was removed under reduced pressure and the residue was

(13) Cardoso, A. M.; Clark, R. J. H.; Moorhouse, S. J. Chem. Soc., Dalton Trans. 1980, 1156. extracted with $\mathrm{CH}_{2} \mathrm{Cl}_{2}(10 \mathrm{~mL}, 5 \mathrm{~mL}, 5 \mathrm{~mL})$. After filtration through Celite, the green solution was concentrated to ca. one-third of the original volume. Heptane $(10 \mathrm{~mL})$ was added to precipitate a green solid, which was then washed with heptane $(2 \times 5 \mathrm{~mL})$ and dried under vacuum. Yield: $0.588 \mathrm{~g}, 75 \%$. The compound can be recrystallized by diffusion of a heptane layer into a toluene solution.

Reaction between $\mathrm{CpNbCl}_{4}$ and $\mathrm{PMe}_{3}$ (1:2.5 ratio) in THF. Formation of $\mathrm{PHMe}_{3}{ }^{+} \mathrm{Cl}^{-}$. To a THF solution $(15 \mathrm{~mL})$ of $\mathrm{CpNbCl}_{4}$ $(0.318 \mathrm{~g}, 1.06 \mathrm{mmol})$ was added $\mathrm{PMe}_{3}(0.280 \mathrm{~mL}, 2.71 \mathrm{mmol})$, immediately producing a red-orange solution. After overnight stirring, a white precipitate forms along with a green solution. The white solid was filtered, washed with heptane $(3 \times 5 \mathrm{~mL})$, and dried under vacuum. Yield: $0.056 \mathrm{~g}, 86 \%$. ' $\mathrm{H}$-NMR $\left(\mathrm{D}_{2} \mathrm{O}\right.$, room temperature, $\left.\delta\right): 1.70(\mathrm{~d}$, $\left.J_{\mathrm{HP}}=15.7 \mathrm{~Hz}, \mathrm{PDM} e_{3}\right) .{ }^{31} \mathrm{P}\left\{{ }^{1} \mathrm{H}\right\}-\mathrm{NMR}\left(\mathrm{D}_{2} \mathrm{O}\right.$, room temperature, $\left.\delta\right)$ : $-3.14\left(\mathrm{t}, J_{\mathrm{PD}}=76.8 \mathrm{~Hz}\right)$.

General Procedure for Monitoring the Reaction of $\mathrm{CpNbCl}_{4}$ with L. THF solutions or toluene suspensions of $\mathrm{CpNbCl}_{4}$ (ca. $100 \mathrm{mg}$ of $\mathrm{CpNbCl}_{4}$ in ca. $10 \mathrm{~mL}$ of the solvent) were treated with the appropriate amount of $\mathrm{L}\left(\mathrm{L}=\mathrm{PMe}_{3}, \mathrm{PMe}_{2} \mathrm{Ph}\right.$, and $\mathrm{PMePh}_{2}$; either 1 or 2.5 equiv). The reactions were allowed to proceed for at least $12 \mathrm{~h}$ while stirring at room temperature. In all cases a white precipitate was observed. In the reaction between $\mathrm{CpNbCl}_{4}$ and 2.5 equiv of $\mathrm{PMe}_{3}$, the final solution had a green color, while the corresponding solutions deriving from the $\mathrm{PMe}_{2} \mathrm{Ph}$ and $\mathrm{PMePh}_{2}$ were reddish-purple. The resulting solutions were analyzed by EPR. Double integration of the EPR signals was performed and the concentration of the $\mathrm{Nb}$ (IV) material was determined by comparison with a reference solution of $\mathrm{CpNbCl}_{3}\left(\mathrm{PMe}_{3}\right)_{2}$ of known concentration.

Solvent Dependence Study of the Reaction of $\mathrm{CpNbCl}_{4} \mathrm{~L}$ with 1.5 equiv of $\mathrm{L}$. THF and toluene solutions of $\mathrm{CpNbCl}_{4} \mathrm{~L}\left(\mathrm{~L}=\mathrm{PMe}_{3}\right.$, $\mathrm{PMe}_{2} \mathrm{Ph}$, and $\mathrm{PMePh}_{2} ; \mathrm{ca} .3 \times 10^{-2} \mathrm{M}$ ) were treated with 1.5 equiv of the corresponding $\mathrm{L}$. An aliquot of the solution was removed and placed in a sealed $3 \mathrm{~mm}$ glass tube. The reactions were monitored by EPR and the amount of $\mathrm{Nb}(\mathrm{IV})$ formed determined as previously described.

Reaction of $\mathrm{CpNbCl}_{4}$ with 2.5 equiv of $\mathbf{P P h}_{3}$. $\mathrm{CpNbCl}_{4}(0.344 \mathrm{~g}$, $1.15 \mathrm{mmol})$ was dissolved in THF $(20 \mathrm{~mL})$ containing $\mathrm{PPh}_{3}(0.754 \mathrm{~g}$. $2.88 \mathrm{mmol}$ ). The resulting red solution was stirred at room temperature for 7 days, showing no noticeable change. 'H-NMR and EPR analysis of the solution indicated no reduction products as well as no adduct formation.

X-ray Crystallography for $\mathrm{CpNbCl}_{4}\left(\mathrm{PMePh}_{2}\right)$. A red crystal with dimensions $0.50 \times 0.50 \times 0.50 \mathrm{~mm}$ was glued to the inside of a glass capillary and mounted on the Enraf-Nonius CAD-4 diffractometer. The crystal's final cell parameters and crystal orientation matrix were determined from 25 reflections in the range $10.1<\theta<19.6^{\circ}$ and confirmed by axial photographs. Three nearly orthogonal standard reflections were monitored at $1 \mathrm{~h}$ intervals of $\mathrm{X}$-ray exposure during the collection of intensity data and showed no significant variation in intensity. The data were corrected for Lorentz and polarization, but not for absorption $\left(T_{\max } / T_{\min }=1.13\right.$ from five $\psi$-scan reflections). The space group was uniquely determined by the systematic absences from the data. Direct methods allowed the location of the six "heavy atoms" $(\mathrm{Nb}, \mathrm{Cl}$ and $\mathrm{P})$, and the other non-hydrogen atoms were located from 
Table 2. Crystallographic Data for $\mathrm{CpNbCl}_{4}\left(\mathrm{PMePh}_{2}\right)^{\cdot 1 / 2} \mathrm{C}_{7} \mathrm{H}_{8}$

$$
\begin{array}{ll}
\hline \mathrm{C}_{21.5} \mathrm{H}_{22} \mathrm{Cl}_{4} \mathrm{NbP} & \text { fw 546.07 } \\
a=23.818(2) \AA & \text { space group: } C 2 / c(\text { No. 15) } \\
b=12.4719(10) \AA & T=20(2) \mathrm{K} \\
c=15.8137(12) \AA & \lambda=0.71069 \AA \\
\beta=106.365(7)^{\circ} & Q_{\text {calcd }}=1.609 \mathrm{~g} / \mathrm{cm}^{3} \\
\mathrm{~V}=4507.2(6) \AA^{3} & \mu=6.03 \mathrm{~cm}^{-1} \\
Z=8 & \text { transm coeff }=0.8839-0.9990 \\
& R^{a}=0.0349 \\
& R_{\mathrm{w}}{ }^{b}=0.0744 \\
& { }^{a} R=\sum \| F_{\mathrm{o}}|-| F_{\mathrm{c}}|| / \Sigma\left|F_{\mathrm{o}}\right| \cdot{ }^{b} R_{\mathrm{w}}=\left[\sum w\left(\left|F_{\mathrm{o}}\right|^{2}-\left|F_{\mathrm{c}}\right|^{2}\right)^{2} / \Sigma w\left(\left|F_{\mathrm{o}}\right|^{2}\right)^{2}\right]^{1 / 2} ; \\
w=1 / \sigma^{2}\left(\left|F_{\mathrm{o}}\right|\right) . &
\end{array}
$$

Table 3. Atomic Coordinates $\left(\times 10^{4}\right)$ and Equivalent Isotropic Displacement Parameters $\left(\AA^{2} \times 10^{3}\right)$ for $\mathrm{CpNbCl}_{4}\left(\mathrm{PMePh}_{2}\right)^{\cdot 1}{ }_{2} \mathrm{C}_{7} \mathrm{H}_{8}{ }^{a}$

\begin{tabular}{crrrr}
\hline & $x$ & $y$ & $z$ & $U(\mathrm{eq})^{b}$ \\
\hline $\mathrm{Nb}(1)$ & $1990(1)$ & $3446(1)$ & $2277(1)$ & $38(1)$ \\
$\mathrm{Cl}(1)$ & $1527(1)$ & $1819(1)$ & $2564(1)$ & $47(1)$ \\
$\mathrm{Cl}(2)$ & $2527(1)$ & $2437(1)$ & $1456(1)$ & $54(1)$ \\
$\mathrm{Cl}(3)$ & $2107(1)$ & $4960(1)$ & $1373(1)$ & $60(1)$ \\
$\mathrm{Cl}(4)$ & $1159(1)$ & $4432(1)$ & $2423(1)$ & $56(1)$ \\
$\mathrm{P}(1)$ & $1195(1)$ & $2916(1)$ & $673(1)$ & $39(1)$ \\
$\mathrm{C}(11)$ & $1347(2)$ & $3622(3)$ & $-243(3)$ & $53(1)$ \\
$\mathrm{C}(21)$ & $1198(1)$ & $1514(2)$ & $324(2)$ & $41(1)$ \\
$\mathrm{C}(22)$ & $1559(2)$ & $1196(3)$ & $-188(2)$ & $52(1)$ \\
$\mathrm{C}(23)$ & $1547(2)$ & $155(3)$ & $-486(3)$ & $62(1)$ \\
$\mathrm{C}(24)$ & $1186(2)$ & $-579(3)$ & $-274(3)$ & $64(1)$ \\
$\mathrm{C}(25)$ & $829(2)$ & $-296(3)$ & $237(3)$ & $61(1)$ \\
$\mathrm{C}(26)$ & $836(2)$ & $753(3)$ & $537(2)$ & $50(1)$ \\
$\mathrm{C}(31)$ & $420(1)$ & $3162(2)$ & $542(2)$ & $41(1)$ \\
$\mathrm{C}(32)$ & $61(2)$ & $3582(3)$ & $-231(2)$ & $58(1)$ \\
$\mathrm{C}(33)$ & $-531(2)$ & $3732(4)$ & $-334(3)$ & $69(1)$ \\
$\mathrm{C}(34)$ & $-767(2)$ & $3477(3)$ & $330(3)$ & $62(1)$ \\
$\mathrm{C}(35)$ & $-423(2)$ & $3061(3)$ & $1099(3)$ & $58(1)$ \\
$\mathrm{C}(36)$ & $169(2)$ & $2906(3)$ & $1208(2)$ & $49(1)$ \\
$\mathrm{C}(1)$ & $2757(5)$ & $4576(6)$ & $3232(6)$ & $52(3)$ \\
$\mathrm{C}(2)$ & $3009(5)$ & $3500(19)$ & $3222(8)$ & $55(5)$ \\
$\mathrm{C}(3)$ & $2731(6)$ & $2826(7)$ & $3563(8)$ & $48(4)$ \\
$\mathrm{C}(4)$ & $2309(4)$ & $3340(11)$ & $3887(5)$ & $59(4)$ \\
$\mathrm{C}(5)$ & $2337(4)$ & $4458(10)$ & $3685(6)$ & $55(4)$ \\
$\mathrm{C}\left(1^{\prime}\right)$ & $2970(3)$ & $3983(11)$ & $3074(5)$ & $62(3)$ \\
$\mathrm{C}\left(2^{\prime}\right)$ & $2929(5)$ & $2948(10)$ & $3338(6)$ & $57(4)$ \\
$\mathrm{C}\left(3^{\prime}\right)$ & $2534(5)$ & $2896(7)$ & $3795(6)$ & $55(3)$ \\
$\mathrm{C}\left(4^{\prime}\right)$ & $2282(4)$ & $3954(13)$ & $3850(6)$ & $63(4)$ \\
$\mathrm{C}\left(5^{\prime}\right)$ & $2558(6)$ & $4642(7)$ & $3415(7)$ & $53(4)$ \\
& & & & \\
0 & & &
\end{tabular}

${ }^{a}$ Atoms $\mathrm{C}(1)-\mathrm{C}(5)$ and $\mathrm{C}\left(1^{\prime}\right)-\mathrm{C}\left(5^{\prime}\right)$ have a sof $=0.5 .^{b} U(\mathrm{eq})$ is defined as one third of the trace of the orthogonalized $U_{i j}$ tensor.

subsequent difference-Fourier maps, including a toluene molecule that sits on a 2-fold axis. Hydrogen atoms were included at calculated positions. Refinement continued with all non-hydrogen atoms treated anisotropically. Refinement proceeded smoothly in all parts of the molecule expect for the $\mathrm{Cp}$ ring. Removal of the $\mathrm{Cp}$ atoms and relocation with a difference-Fourier map allowed the identification of two independent orientations of the $\mathrm{Cp}$ ring. Refinement of the occupancies of the two groups gave an approximate value of 0.5 for each, so this value was fixed and the two rings were now allowed to refine. The ten $\mathrm{Cp}$ ring hydrogen atoms were now included and placed in calculated positions and allowed to ride on the corresponding carbon atoms during the last cycles of refinement. Selected crystal data are collected in Table 2, positional and equivalent isotropic thermal parameters are listed in Table 3, and selected bond distances and angles are reported in Table 4.

\section{Results}

Syntheses, Reactivity, and Spectroscopic Characterization. The reaction of $\mathrm{CpNbCl}_{4}$ with $\mathrm{PMe}_{x} \mathrm{Ph}_{3-x}(x=0,1,2,3)$ was first carried out in a 1:1 ratio in toluene. The addition of $\mathrm{PPh}_{3}$ did not lead to any reaction, nor was any reaction observed when the two compounds were mixed in THF, as shown by NMR monitoring. On the other hand, the addition of $\mathrm{PMePh}_{2}$ in toluene resulted in the rapid dissolution of the starting material
Table 4. Selected bond distances ( $\AA$ ) and angles (deg) for $\mathrm{CpNbCl}_{4}\left(\mathrm{PMePh}_{2}\right) \cdot 1 /{ }_{2} \mathrm{C}_{7} \mathrm{H}_{8}{ }^{a}$

\begin{tabular}{lrll}
\hline $\mathrm{Nb}(1)-\mathrm{Cl}(1)$ & $2.4127(8)$ & $\mathrm{Nb}(1)-\mathrm{Cl}(4)$ & $2.3965(8)$ \\
$\mathrm{Nb}(1)-\mathrm{Cl}(2)$ & $2.4168(8)$ & $\mathrm{Nb}(1)-\mathrm{P}(1)$ & $2.7844(9)$ \\
$\mathrm{Nb}(1)-\mathrm{Cl}(3)$ & $2.4315(9)$ & $\mathrm{Nb}(1)-\mathrm{CNT}$ & $2.144(8)$ \\
& & & \\
$\mathrm{Cl}(1)-\mathrm{Nb}(1)-\mathrm{Cl}(2)$ & $90.13(3)$ & $\mathrm{Cl}(3)-\mathrm{Nb}(1)-\mathrm{P}(1)$ & $79.02(3)$ \\
$\mathrm{Cl}(1)-\mathrm{Nb}(1)-\mathrm{Cl}(3)$ & $153.88(3)$ & $\mathrm{Cl}(4)-\mathrm{Nb}(1)-\mathrm{P}(1)$ & $80.89(3)$ \\
$\mathrm{Cl}(1)-\mathrm{Nb}(1)-\mathrm{Cl}(4)$ & $88.84(3)$ & $\mathrm{CNT}-\mathrm{Nb}-\mathrm{Cl}(1)$ & $102.3(3)$ \\
$\mathrm{Cl}(1)-\mathrm{Nb}(1)-\mathrm{P}(1)$ & $75.07(3)$ & $\mathrm{CNT}-\mathrm{Nb}-\mathrm{Cl}(2)$ & $102.1(3)$ \\
$\mathrm{Cl}(2)-\mathrm{Nb}(1)-\mathrm{Cl}(3)$ & $85.55(3)$ & $\mathrm{CNT}-\mathrm{Nb}-\mathrm{Cl}(3)$ & $103.8(4)$ \\
$\mathrm{Cl}(2)-\mathrm{Nb}(1)-\mathrm{Cl}(4)$ & $153.56(3)$ & $\mathrm{CNT}-\mathrm{Nb}-\mathrm{Cl}(4)$ & $103.9(3)$ \\
$\mathrm{Cl}(2)-\mathrm{Nb}(1)-\mathrm{P}(1)$ & $73.34(3)$ & $\mathrm{CNT}-\mathrm{Nb}-\mathrm{P}(1)$ & $174.6(2)$ \\
$\mathrm{Cl}(3)-\mathrm{Nb}(1)-\mathrm{Cl}(4)$ & $83.86(3)$ & &
\end{tabular}

${ }^{a} \mathrm{CNT}=$ center of gravity of atoms $\mathrm{C}(1)-\mathrm{C}(5)$ and $\mathrm{C}\left(1^{\prime}\right)-\mathrm{C}\left(5^{\prime}\right)$.

and formation of a red-orange solution, whose ${ }^{1} \mathrm{H}-$ and ${ }^{31} \mathrm{P}-$ NMR properties where fully consistent with formation of the desired adduct, $\mathrm{CpNbCl}_{4}\left(\mathrm{PMePh}_{2}\right)$ (eq 1). The product was isolated in good yields and characterized by elemental analysis, ${ }^{1} \mathrm{H}$ - and ${ }^{31} \mathrm{P}-\mathrm{NMR}$ (see Table 1), and by an X-ray structural determination (see below). No phosphorus coupling is observed for the $\mathrm{Cp}$ protons. This is not unusual, as $\mathrm{Cp}$ protons show only small couplings to metal-bound phosphorus nuclei, these couplings being very sensitive to the $\mathrm{Cp}-\mathrm{M}-\mathrm{P}$ angle. For instance, only the phosphorus trans to $\mathrm{Cl}$ in compound $\mathrm{CpMoCl}$ $\left(\mathrm{PMe}_{3}\right)_{3}$ gives an observable coupling. ${ }^{14}$

Contrary to the adducts with $\mathrm{PMe}_{3}$ and $\mathrm{PEt}_{3}$ described by Leigh et al. ${ }^{9}$ and to the $\mathrm{P}(\mathrm{OMe})_{3}$ and dppe derivatives reported by Green, ${ }^{10}$ this compound does not show particularly unusual lability and its solutions in $\mathrm{C}_{6} \mathrm{D}_{6}$ and THF do not decompose over 1 week at room temperature; ${ }^{1} \mathrm{H}-\mathrm{NMR}$ monitoring did not show loss of intensity, and EPR monitoring indicates that no paramagnetic product is formed (vide infra).

The reactions of $\mathrm{CpNbCl}_{4}$ with $\mathrm{PMe}_{3}$ and $\mathrm{PMe}_{2} \mathrm{Ph}$ in toluene proceed apparently as the corresponding $\mathrm{PMePh}_{2}$ reaction described above (eq 1). The ${ }^{1} \mathrm{H}$ - and ${ }^{31} \mathrm{P}-\mathrm{NMR}$ monitoring of the resulting red-orange solutions indicate clean formation of the expected monoadducts. However, a closer inspection of the reaction mixtures revealed the presence of small amounts of white precipitates. The precipitate that formed during the $\mathrm{PMe}_{3}$ reaction was isolated and identified as the trimethylphosphonium salt $\left[\mathrm{PHMe}_{3}\right]^{+} \mathrm{Cl}^{-}$by ${ }^{1} \mathrm{H}-$ and ${ }^{31} \mathrm{P}-\mathrm{NMR}$. The ${ }^{31} \mathrm{P}-$ $\left\{{ }^{1} \mathrm{H}\right\}$-NMR in $\mathrm{D}_{2} \mathrm{O}$ shows a $1: 1: 1$ triplet $\left(\mathrm{J}_{\mathrm{PD}}=76.8 \mathrm{~Hz}\right)$ at $-3.14 \mathrm{ppm},{ }^{15}$ in agreement with the expected exchange of the acidic proton with $\mathrm{D}_{2} \mathrm{O}$. The formation of a phosphonium salt immediately warned us of the possibility of a reduction reaction, by analogy with the established reactions of phosphines with $\mathrm{MoCl}_{3}$ (with formation of both $\mathrm{Mo}^{\mathrm{III}}$ and $\mathrm{Mo}^{\mathrm{II}}$ products) ${ }^{16}$ and $\mathrm{FeCl}_{3}$ (with formation of $\mathrm{Fe}^{\mathrm{III}}$ and $\mathrm{Fe}^{\mathrm{II}}$ products), ${ }^{17}$ in both cases the formation of phosphonium salts also being observed. For the Fe reaction, the formation of chlorinated hydrocarbons was also verified by gas-chromatography. ${ }^{17 \mathrm{a}} \mathrm{A}$ related reaction is that of $\mathrm{L}=\mathrm{PMe}_{3}$ or $\mathrm{PHEt}_{2}$ with $\mathrm{CpTiCl}_{3}$, which yields both $\mathrm{CpTi}^{\mathrm{IV}} \mathrm{Cl}_{3}(\mathrm{~L})$ and ca. $2 \%$ of $\mathrm{CpTi}^{\mathrm{III}} \mathrm{Cl}_{2}(\mathrm{~L})_{2}$, although for this particular reaction the formation of neither chlorinated solvent nor a phosphonium salt was reported. ${ }^{18}$

The formation of paramagnetic materials in the $\mathrm{CpNbCl}_{4} /$ $\mathrm{PMe}_{3}$ or $\mathrm{PMe}_{2} \mathrm{Ph}$ reactions was confirmed by more careful ${ }^{1} \mathrm{H}-$ NMR and by EPR measurements. For instance, for the $\mathrm{PMe}_{3}$

(14) Abugideiri, F.; Kelland, M. A.; Poli, R.; Rheingold, A. L. Organometallics 1992, 11, 1303.

(15) Lit.: $\delta 2.8 \mathrm{in}$ an unspecified solvent, $J_{\mathrm{PH}}=495 \mathrm{~Hz}$ (calculated $J_{\mathrm{PD}}=$ $76.0 \mathrm{~Hz}$ ). Moedritzer, K.; Maier, L.; Groenweghe, L. C. D. J. Chem. Eng. Data 1962, 7, 307.

(16) Cotton, F. A.; Poli, R. Inorg. Chem. 1987, 26, 1514

(17) (a) Walker, J. D.; Poli, R. Inorg. Chem. 1989, 28, 1793. (b) Dunbar, K. R.; Quillevéré, A. Angew. Chem., Int. Ed. Engl. 1993, 32, 293.

(18) Nadasdi, T. T.; Stephan, D. W. Inorg. Chem. 1993, 32, 5933. 


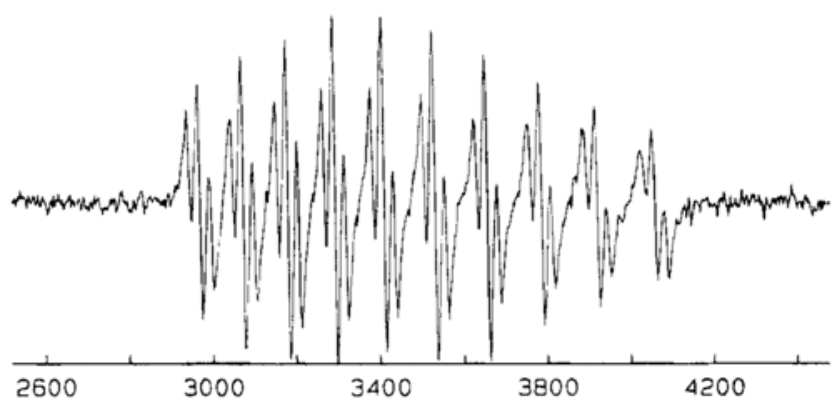

[G]

Figure 1. EPR spectrum $\left(\mathrm{X}\right.$ band) of $\mathrm{CpNbCl}{ }_{3}\left(\mathrm{PMe}_{3}\right)_{2}$ (solvent $=\mathrm{THF}$, room temperature).

reaction, the ${ }^{1} \mathrm{H}-\mathrm{NMR}$ taken on a larger sweep width shows two broad bands centered at ca. 10 and $-20 \mathrm{ppm}$. The EPR spectrum shows a decet of triplets (Figure 1, $g=1.988, a_{\mathrm{Nb}}=$ $\left.121.0 \mathrm{G}, a_{\mathrm{P}}=17.8 \mathrm{G}\right)$, therefore suggesting that the reduction product is $\mathrm{CpNbCl}_{3}\left(\mathrm{PMe}_{3}\right)_{2}$. This $\mathrm{Nb}$ (IV) compound, which was not previously reported in the literature, has been subsequently synthesized from $\mathrm{CpNbCl}_{4} / \mathrm{Na} / \mathrm{PMe}_{3}$ in a 1:1:2 ratio, isolated, and fully characterized, confirming all the assignments made. Analogous observations were made for the $\mathrm{PMe}_{2} \mathrm{Ph}$ reaction, the reduction product having again the stoichiometry $\mathrm{CpNbCl}_{3}\left(\mathrm{PMe}_{2} \mathrm{Ph}\right)_{2}$ (decet of triplets, $g=1.997, a_{\mathrm{Nb}}=120.3$ $\left.\mathrm{G}, a_{\mathrm{P}}=24.1 \mathrm{G}\right)$. The EPR spectra observed for compounds $\mathrm{CpNbCl}_{3}\left(\mathrm{PMe}_{x} \mathrm{Ph}_{3-x}\right)_{2}(x=2,3)$ compare quite well with that observed for the known isoelectronic $\mathrm{CpNbCl}_{3}(\mathrm{dmpe})$ ( $g=$ $1.971 a_{\mathrm{Nb}}=135 \mathrm{G}$ and $\left.a_{\mathrm{P}}=14.3 \mathrm{G}\right){ }^{7}$

We therefore propose that the reduction takes place according to the stoichiometry illustrated in eq $2(\mathrm{~S}-\mathrm{H}=$ solvent molecule).

$$
\begin{aligned}
& \mathrm{CpNbCl}_{4}+\mathrm{PMe}_{x} \mathrm{Ph}_{3-x} \rightarrow \\
& \mathrm{CpNbCl}_{4}\left(\mathrm{PMe}_{x} \mathrm{Ph}_{3-x}\right)(x=1,2,3) \\
& 2 \mathrm{CpNbCl}_{4}+5 \mathrm{PMe}_{x} \mathrm{Ph}_{3-x}+\mathrm{S}-\mathrm{H} \rightarrow \\
& 2 \mathrm{CpNbCl}_{3}\left(\mathrm{PMe}_{x} \mathrm{Ph}_{3-x}\right)_{2}+\left[\mathrm{PHMe}_{x} \mathrm{Ph}_{3-x}\right]^{+}+ \\
& \mathrm{S}-\mathrm{Cl}(x=2,3)
\end{aligned}
$$

In order to quantify the amount of adduct vs the amount of reduced material, the following experiment was run. Samples of $\mathrm{CpNbCl}_{4}$ were treated with 2.5 equiv of each phosphine in THF. This stoichiometry was chosen in order to allow the reduction reactions to proceed to completion, if this were the preferred situation (eq 2). The amount of reduction products in the solutions were calculated by double integration of the EPR signal vs standard signals of the corresponding solutions which were obtained by reacting $\mathrm{CpNbCl}_{4}, \mathrm{Na}$, and the phosphine in a 1:1:2 ratio. Under these conditions, the $\mathrm{PMe}_{3}$ reaction proceeds to $100 \%$ reduction, compared to only $42 \%$ reduction for the corresponding $\mathrm{PMe}_{2} \mathrm{Ph}$ system. The same test was also performed on the $\mathrm{PMePh}_{2}$ reaction, with the result that $28 \%$ reduction occurs after $24 \mathrm{~h}$ at room temperature. However, both $\mathrm{PMe}_{2} \mathrm{Ph}$ and $\mathrm{PMePh}_{2}$ systems do eventually proceed to complete reduction on a longer time scale.

It is also to be noted that the formation of a white precipitate accompanies the reactions. For the $\mathrm{PMePh}_{2}$ system, the EPR signal of the $\mathrm{Nb}(\mathrm{IV})$ product is broad, showing only coupling to the niobium atom $\left(g=1.989, a_{\mathrm{Nb}}=124.3 \mathrm{G}\right)$. Since the signal does not significantly sharpen upon cooling to $-60^{\circ} \mathrm{C}$, we cannot establish with certainty the stoichiometry of the reduction product, the most likely possibilities being $\mathrm{CpNbCl}_{3}$ $\left(\mathrm{PMePh}_{2}\right)_{n}(n=1$ or 2$)$. We remind the reader that, when the $\mathrm{PMePh}_{2}$ reaction was carried out in toluene with only 1 equiv

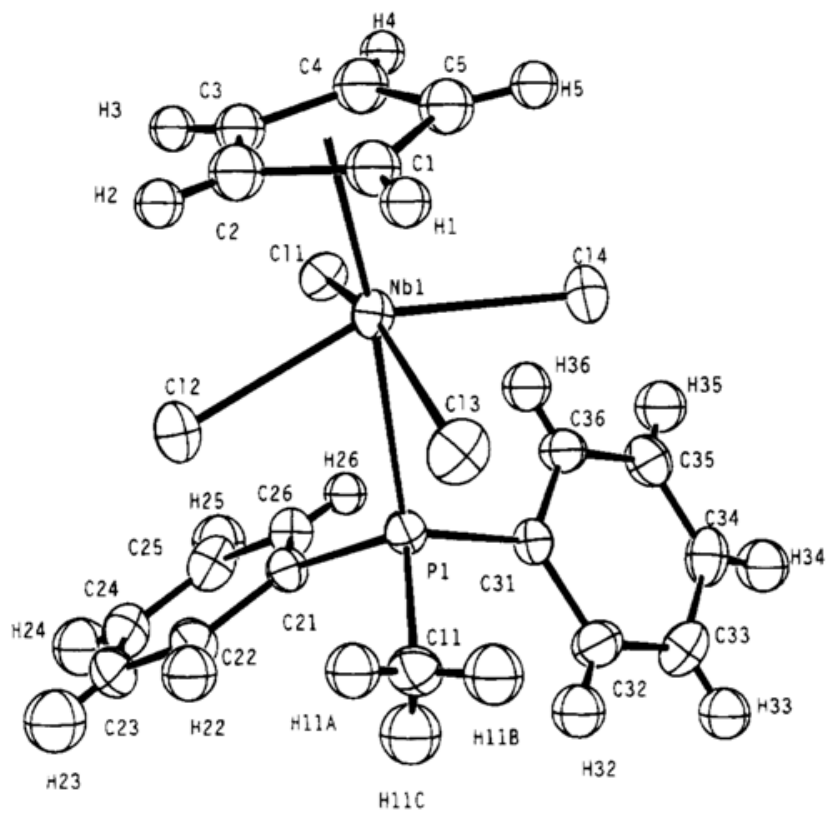

Figure 2. ORTEP view of the $\mathrm{CpNbCl}_{4}\left(\mathrm{PMePh}_{2}\right)$ molecule. Only one orientation of the $\mathrm{Cp}$ ring is shown for clarity. The thermal ellipsoids for non-hydrogen atoms are drawn at the $50 \%$ probability level and the hydrogen atoms are drawn with arbitrary radii.

of the ligand per $\mathrm{Nb}$, no reduction occurred (no EPR signal and no phosphonium chloride precipitate). A comparative study of the reduction rate in THF and toluene shows a considerable solvent dependence, the initial rate of reduction being approximately 5 times greater in THF than in toluene.

Analytically pure samples of $\mathrm{CpNbCl}_{4}\left(\mathrm{PMe}_{3}\right)$ and $\mathrm{CpNbCl}_{4}-$ $\left(\mathrm{PMe}_{2} \mathrm{Ph}\right)$ were eventually obtained by adding substoichiometric amounts of $\mathrm{PMe}_{3}$ and $\mathrm{PMe}_{2} \mathrm{Ph}$ to toluene suspensions of $\mathrm{CpNbCl}_{4}$ and by rapidly working up the resulting red-orange solutions. Once the compounds are isolated, they do not show any tendency to decompose by reduction or in any other way. Solutions of $\mathrm{CpNbCl}_{4}\left(\mathrm{PMe}_{3}\right)$ in either toluene or THF are stable when kept under an inert atmosphere for as much as one week, ${ }^{1} \mathrm{H}-\mathrm{NMR}$ and EPR monitoring showing the presence of only unchanged starting material and no formation of $\mathrm{Nb}(\mathrm{IV})$ species.

X-ray Structure of $\mathrm{CpNbCl}_{4}\left(\mathrm{PMePh}_{2}\right)$. A view of $\mathrm{CpNbCl}_{4}$ $\left(\mathrm{PMePh}_{2}\right)$, the first phosphine adduct of $\mathrm{CpNbCl}_{4}$ to be crystallogaphically characterized, is shown in Figure 2 and relevant bond distances and angles are in Table 4. The molecule exhibits a distorted pseudooctahedral geometry with the phosphine ligand trans to the $\mathrm{Cp}$ ring. The ring is bound to the $\mathrm{Nb}$ in an $\eta^{5}$ fashion and the four chlorine atoms are bent away from it and toward the phosphine ligand. A similar distortion is observed for the 2,6-dimethylphenylisocyanide adduct of $\mathrm{Cp} * \mathrm{NbCl}_{4}{ }^{12}$ The CNT-Nb-Cl angles have values between 102.1 to 103.9 for $\mathrm{CpNbCl}_{4}\left(\mathrm{PMePh}_{2}\right)$, comparable to those of the isocyanide complex with values ranging from 104.0 to 104.9. ${ }^{12}$

The $\mathrm{Nb}-\mathrm{CNT}$ and $\mathrm{Nb}-\mathrm{Cl}$ distances are also quite comparable in the title compound and in the isocyanide complex (values for the latter are $\mathrm{Nb}-\mathrm{CNT}, 2.169$ (11) $\AA ; \mathrm{Nb}-\mathrm{Cl}, 2.396$ (3) $-2.435(3) \AA) .^{12}$ The $\mathrm{Nb}-\mathrm{P}$ distance, 2.7844 (9) $\AA$, is rather long. The only other $\mathrm{Nb}(\mathrm{V})-\mathrm{P}$ distance reported in the literature is $2.640(3) \AA$ for $\mathrm{Nb}(\mathrm{O}) \mathrm{Cl}_{3}\left(\mathrm{PMe}_{3}\right)_{3}{ }^{19}$ As possible causes for this lengthening, we may advance a strong trans influence of the $\mathrm{Cp}$ ligand and/or a steric pressure due to the bending of the four $\mathrm{Nb}-\mathrm{Cl}$ bonds.

(19) Gibson, V. C.; Kee, T. P.; Sorrell, R. M.; Bashall, A. P.; McPartlin, M. Polyhedron 1988, 7, 2221. 


\section{Discussion}

The stability of monophosphine adducts of $\mathrm{CpNbCl}_{4}$ has been a confusing issue in the precedent literature. In order to understand the essence of the confusion, reactions of $\mathrm{CpNbCl}_{4}$ with various tertiary phosphines have been carried out with ${ }^{1} \mathrm{H}$ NMR and EPR monitoring. The result of our investigations is that a reduction process is triggered by excess phosphine, this probably occurring with release of chlorine radicals, which eventually chlorinate the solvent. The resulting $\mathrm{HCl}$ is eventually trapped by the phosphine to give the observed phosphonium salt (see Scheme 1). The previously reported difficulties in isolating phosphine adducts of $\mathrm{CpNbCl}_{4}$ may therefore be simply related to the formation of these reduction by-products.

\section{Scheme 1}

$$
\begin{gathered}
\mathrm{CpNbCl}_{4}+\mathrm{L} \rightarrow \mathrm{CpNbCl}_{4} \mathrm{~L} \\
\mathrm{CpNbCl}_{4} \mathrm{~L}+\mathrm{L} \rightarrow \mathrm{CpNbCl}_{3} \mathrm{~L}_{2}+\mathrm{Cl}^{\bullet} \\
2 \mathrm{Cl}^{\bullet}+\mathrm{S}-\mathrm{H} \rightarrow \mathrm{S}-\mathrm{Cl}+\mathrm{HCl} \\
\mathrm{HCl}+\mathrm{L} \rightarrow[\mathrm{LH}]^{+} \mathrm{Cl}^{-}
\end{gathered}
$$

The reduction process takes place subsequently to the formation of the $\mathrm{Nb}(\mathrm{V})-$ phosphine adduct. This is shown by the stability of these $\mathrm{Nb}(\mathrm{V})$-phosphine adducts in the absence of excess phosphine (this also proves the irreversibility of the coordination step, i.e. eq 3) and by their reaction with excess phosphine to proceed to the reduction products. Also, spectroscopically and analytically pure $\mathrm{Nb}(\mathrm{V})$-phosphine adducts could be isolated by working under kinetically controlled conditions with substoichiometric amounts of the ligand. The formation of minor amounts of reduction products for $\mathrm{L}=\mathrm{PMe}_{3}$ and $\mathrm{PMe}_{2} \mathrm{Ph}$ even when using 1 equiv of $\mathrm{L}$ depends on the fact that the rate of the reduction reaction (eq 4) is not insignificant with respect to the rate of ligand addition (eq 3 ). The use of THF as solvent increases the amount of reduction vs addition product with respect to toluene.

A possibility for the intimate mechanism of the reduction step (eq 4) involves reversible dissociation of a chlorine radical from $\mathrm{CpNbCl}_{4} \mathrm{~L}$ to afford $\mathrm{CpNbCl}_{3} \mathrm{~L}$ and $\mathrm{Cl}^{*}$ in a radical cage. When excess phosphine is present, the 15 -electron complex is trapped to form the stable 17-electron $\mathrm{CpNbCl}_{3} \mathrm{~L}_{2}$ product and subsequently $\mathrm{Cl}^{*}$, now released from the cage, continues the reaction. This mechanism, however, would lead one to predict a slow decomposition of the $\mathrm{Nb}(\mathrm{V})$ complexes in the absence of excess phosphine, while none was observed over 1 week at room temperature. In addition, this mechanism is in further disaccord with the observed trend of reactivity $\left(\mathrm{PMe}_{3}>\mathrm{PMe}_{2-}\right.$ $\mathrm{Ph}>\mathrm{PMePh}_{2}$ ), because the better donor $\mathrm{PMe}_{3}$ should better stabilize the higher oxidation state. This is confirmed by a cyclic voltammetric study: $\mathrm{CpNbCl}_{4} \mathrm{~L}$ compounds undergo a quasireversible reduction process at $E_{1 / 2}=-0.62\left(\mathrm{PMe}_{3}\right),-0.54$ $\left(\mathrm{PMe}_{2} \mathrm{Ph}\right)$, and $-0.40 \mathrm{~V}\left(\mathrm{PMePh}_{2}\right)$, respectively, with respect to $\mathrm{Cp}_{2} \mathrm{Fe}^{+} / \mathrm{Cp}_{2} \mathrm{Fe}$. A more likely possibility is that the excess phosphine coordinates to the $\mathrm{Nb}(\mathrm{V})$ center first, possibly through preliminary ring slippage to a $\eta^{3}$ configuration, followed by loss of $\mathrm{Cl}^{\circ}$. With $\mathrm{PPh}_{3}$, no reduction is observed, presumably because the phosphine is too sterically encumbering and/or not sufficiently basic to afford a stable $\mathrm{Nb}(\mathrm{V})$ - phosphine adduct.

For the previously described $\mathrm{CpTiCl}_{3} / \mathrm{PMe}_{3}$ system, ${ }^{18}$ only $2 \%$ reduction was observed by carrying out the reaction in a $1: 1$ ratio in THF. The same reaction with a $2.5 \mathrm{~mol}$ amount of the phosphine (i.e. the conditions necessary to lead to complete reduction) has not been reported. For the $\mathrm{CpNbCl}_{4}$ system we have on the other hand established that an excess of the phosphine, given sufficient time and provided that the phosphine coordinates first, reduces the $\mathrm{Nb}$ system completely and that the rate of reduction depends on the phosphine nature.

A suggestion of one of the reviewers is that the $\mathrm{HCl}$ used for the formation of the phosphonium salts could apise from the hydrolysis of the $\mathrm{Nb}(\mathrm{V})$ material. Indeed, $\mathrm{CpNbCl}_{4}$ is known to be hydrolytically sensitive. ${ }^{10}$ However, we have demonstrated that (i) metal reduction and formation of the phosphonium salts follow phosphine coordination (a phosphine adduct should be less hydrolytically sensitive than its $\mathrm{CpNbCl}_{4}$ precursor) and (ii) when using $\mathrm{PPh}_{3}$ (which does not coordinate), no phosphonium salt or reduced $\mathrm{Nb}$ complexes form. In addition, an adventitious amount of $\mathrm{H}_{2} \mathrm{O}$ in the system would give rise to small and irreproducible amounts of phosphonium salt, whereas we always observe the formation of the phosphonium salt to be coupled to the metal reduction, which proceeds quantitatively when 2.5 equiv of a coordinating phosphine is used.

Finally, compounds $\mathrm{CpNbCl}_{3}\left(\mathrm{PMe}_{x} \mathrm{Ph}_{3-x}\right)_{2}(x=2,3)$ are the first 17-electron adducts of $\mathrm{CpNbCl}_{3}$ with monodentate phosphines. Adducts with 17-electrons and bidentate phosphines, e.g. $\mathrm{CpNbCl}_{3}(\mathrm{dmpe})^{7}$ and the structurally characterized $\mathrm{CpNbCl}_{3}$ (dppe), ${ }^{8}$ and 15-electron adducts with monodentate phosphines, e.g. $\mathrm{CpNbCl}_{3}\left(\mathrm{PMe}_{2} \mathrm{Ph}\right),{ }^{9 \mathrm{~b}}$ have previously been reported. One curious discrepancy, i.e. our spectroscopic observation of a bis$\mathrm{PMe}_{2} \mathrm{Ph}$ adduct and the report of only a mono- $\mathrm{PMe}{ }_{2} \mathrm{Ph}$ adduct by zinc reduction of $\mathrm{CpNbCl}_{4}$ with 2 equiv of the phosphine ligands, ${ }^{9 \mathrm{~b}}$ is currently under investigation, as is the reductive chemistry of these materials.

Acknowledgment. This work was supported in part by the donors of the Petroleum Research Fund (Grant 25184-AC3C). Additional support from the Alfred P. Sloan Foundation and the National Science Foundation through awards to R.P. is also gratefully acknowledged. We thank Dr. Paul J. Krusic for kindly making his EPR instrument available to us.

Supplementary Material Available: For the $\mathrm{X}$-ray structural determination of $\mathrm{CpNbCl}_{4}\left(\mathrm{PMePh}_{2}\right)^{1} \cdot 1 / 2 \mathrm{C}_{7} \mathrm{H}_{8}$ : a more detailed text description of crystallographic procedures and full tables crystal data, of distances and angles, anisotropic thermal parameters, and hydrogen and solvent atom coordinates (12 pages). Ordering information is given on any current masthead page. 